\title{
An analysis of causal asyndetic constructions in United States history textbooks
}

\author{
Jason C Fitzgerald
}

\section{Correspondence:}

jason.fitzgerald@wagner.edu

Wagner College, One Campus Road,

Staten Island, New York, NY 10301, USA

\section{包 Springer}

\begin{abstract}
Over the last three decades, an increased focus on engaging K-12 students in historical thinking has highlighted the importance of providing students with direct instruction regarding how causal relationships are formed in text. Many teachers provide this instruction by focusing on explicit causal structures, neglecting implicit forms of causation such as causal asyndetic constructions. Studies of United States history textbooks have found instances of causal asyndetic construction use, similar to the implicit constructions found in studies of spoken and written discourse. This study examines two questions: (1) Do causal asyndetic constructions occur in history textbooks with similar frequency to causal conjunctions and causal material processes? and (2) How is causal asyndetic cohesion signaled in history texts? A mixed methods analysis of two middle school and two high school textbooks demonstrates that causal asyndetic constructions are used as frequently, if not more frequently, than explicit means of expressing causation; they are signaled through authors' uses of modals, mental processes, relational processes, and verbal processes. The use of mental processes to signal causal asyndetic constructions far outnumbered other implicit signals, accounting for $58 \%$ of the total. These findings suggest that teachers need to provide students with instruction about how to identify and make meaning of causal asyndetic constructions as well as causal conjunctions and explicit processes.
\end{abstract}

Keywords: Causal asyndetic constructions; Causation; History; Textbooks

\section{Background}

Causal connections are semantically important for constructing and comprehending history (Achugar and Schleppegrell 2005; Carr 1961; Coffin 2004, 2006; Moss 2005); they explain why events occurred. Without causal connections, it would be difficult to discuss important abstract concepts such as power, privilege, agency, and authority because causal connections provide "an important ordering principle of human perception and human experience" (Noordman and de Blijzer 2000, p. 35) and especially for explaining the relationships between historical events (Novick 1988). Unfortunately, youth are usually taught history via textbooks (Nokes 2010), which often neglect making causal connections between historical events, favoring a chronological narrative (FitzGerald 1979).

When history teachers provide instruction about how to identify and construct causation in text, they often focus on using causal conjunctions between clauses such as because or so (Noordman and de Blijzer 2000) and sometimes on causal processes, realized by verbs such as led to and forced within clauses (Achugar and Schleppegrell

(c) 2014 Fitzgerald; licensee Springer. This is an Open Access article distributed under the terms of the Creative Commons Attribution License (http://creativecommons.org/licenses/by/2.0), which permits unrestricted use, distribution, and reproduction in any medium, provided the original work is properly credited. 
2005). These explicit causal signals are used to teach students about causation at all educational levels - in elementary (Williams et al. 2007), secondary (Meyer et al. 1980), and post-secondary (Meyer and Poon 2001) schools. Implied causal constructions, such as causal asyndetic constructions (CACs), have not been given much attention in the literature. Found in verbal discourse (e.g., Gohl 2000; Lyda 2006) and written discourse (e.g., Blettner 1983; Fitzgerald 2011; Rosette 2009), asyndetic constructions occur when coordination between two clauses is apparent but no overt coordinating conjunction is present (e.g., and, or, but, so, because) (Muller 1991); asyndetic construction are not necessarily causal. Relevant to this study, however, CACs occur when two clauses lack explicit causal connectors between them. For example, instead of writing "Lee retreated because he thought he was outmanned", an author using a CAC might write, "Lee thought he was outmanned. He retreated". By eliminating the causal conjunction because, the author makes the causal connection between the two clauses less explicit, although that connection might still be surmised in context. This study explores the frequency of CAC use in United States history textbooks and the means by which they might be explained semantically, helping K-12 students to better recognize and comprehend texts that employ them.

\section{Causation and history instruction}

Amongst all of the historical writing genres, time and causation are two ordering principles that enable authors to make statements and arguments about the past (Coffin 2006); indeed these two principles are intertwined in all historical works (Rogers 2011). As authors' historical arguments become more sophisticated, however, causation takes a more central role than chronology. By bringing together disparate historical evidence, chronological explanations are often unable to facilitate the arguments historians intend to demonstrate (Novick 1988). Complex nominal groups, causal material processes (CMPs) realized through verbs such as forced, made, and caused, and cohesive structures are frequently used to make causal connections in support of a historical thesis (Coffin 2004). Thus, while both time and causation are important for history students to learn, instruction in how to identify, comprehend, and create causal connections in text is important for developing students' historical discourse skills.

Developing students' historical discourse skills has become increasingly important with the increased instructional focus on historical thinking skills (e.g., VanSledright 2002; Wineburg 2001). To enable students to think historically, teachers provide students with multiple primary and secondary sources about a particular historical topic, asking them to (1) source, (2) closely read, (3) corroborate, and (4) contextualize the texts to produce their own historical interpretations (Fitzgerald 2009). Although the historical interpretation might be presented through various historical genres (e.g., historical account, narrative, argument, etc.) (Coffin 2006), the goal is to enable students to develop their historical analysis and writing skills to a level where they can create sophisticated historical arguments (Levesque 2008).

Unfortunately, the literature on how to teach students to think historically does not often discuss the discourse features that students need to be able to access in order to comprehend and create historical arguments, specifically causation. Most of the studies exploring the impact of historical thinking instructional strategies provide students with graphic 
representations of causation without teaching them how to describe causal connections linguistically (e.g., Kemp 2011; Rogers 2011). When these studies do include linguistic instruction, they often focus on explicit causal signals that merge temporality and causality, such as exacerbated (e.g, "The sinking of the battleship exacerbated tensions and led to war") and ultimately (e.g., "Tensions ultimately started the war") (e.g., Waring 2010). Studies that pair instruction about both historical thinking and the language of history are scarce.

Despite pedagogic efforts to shift history instruction from traditional, textbook-driven teaching to multiple-source historical thinking activities, the ways in which causation is discussed with students in both settings is eerily similar. The graphic representations that only imply causal relationships and the focus on explicit causal signals in historical thinking instruction are similar to the paratextual graphs and inclusion of causal connectors that textbooks use to aid students' causal comprehension (Coffin 2006). Indeed, when teachers use textbook passages to teach students how to identify, comprehend, and create causal connections, they use the same methods discussed above; teachers are only occasionally urged to focus on causal signals (e.g., Meyer and Poon 2001; Williams et al. 2007) or mapping causal events without explicit causal connections (e.g., Ciardiello 2002). It appears that textbook editors and history education scholars of various pedagogic orientations tend to teach causation either graphically or with a limited set of explicit linguistic signals (e.g., because and so).

Unfortunately, these instructional strategies might not help all students access important causal connections between historical events. Reading researchers (e.g., Trabasso and van den Broek 1985; Trabasso et al. 1984; Warren et al. 1979) and linguists (e.g., Noordman and de Blijzer 2000; Schleppegrell and Achugar 2003; Veel and Coffin 1996) not only agree that causation is an important ordering concept for text comprehension but that variations on causal constructions impact readers' mental representations of texts. In addition to neglecting instruction on (1) the impact of causal direction on comprehending historical texts (Noordman and de Blijzer 2000) and (2) the use of CMPs in history texts (Achugar and Schleppegrell 2005), ${ }^{\text {a }}$ instructional studies also neglect to focus on implicit causal connections, such as CACs, that have been identified as troublesome for students' comprehension of history texts (Fitzgerald 2012) in history texts. In order to help all students identify, comprehend, and create sophisticated causal connections, they must be instructed in the various ways that causation is constructed.

\section{Causal relationships}

Despite calls for teachers to choose primary source texts to support history instruction, many teachers continue to use history textbooks as their primary instructional material (Nokes 2010), making textbooks a primary means by which students are exposed to causal constructions. Research indicates that students are exposed to both explicit forms of causation, including causal conjunctions and CMPs (Achugar and Schleppegrell 2005) as well as implicit forms, via cohesion and CACs (Fitzgerald 2011). Instructing students to explore the ways that each form works is important to their understanding of historical text.

\section{Explicit causal relationships}

Causal conjunctions such as because, so, and as a result signal to readers that a causal connection is being made between two discrete events (Meyer and Poon 2001; Williams et al. 
2007). Using connectors limits the number of causal connections that can be made with any particular event; connectors directly link two events to the exclusion of multiple causal factors. Often, when history teachers provide direct instruction for identifying causation, they teach these causal connectors. Here, teaching practice and textbook structure are mutually supportive in teaching a simplistic historical narrative (FitzGerald 1979).

In addition to causal connectors, some verbs can also be used to explicitly realize causal relationships, such as cause and make. Unlike causal conjunctions that express causation between clauses, authors use CMPs to specify causal relationships within the clause structure, forming more densely constructed historical text that might be more difficult for students to comprehend. By examining verbs authors choose to realize specific processes, Achugar and Schleppegrell (2005) illustrate that causal connections can be made less explicit than if causal conjunctions were used, making an important case for exploring the various ways causation is expressed in history textbooks by looking beyond connectors.

\section{Implicit causal relationships}

Due to the breadth of history that they cover, history textbooks have the potential to describe complex situations where many events across time and space may influence a particular event. While dense nominal and verb-groups can make comprehending explicit causation more difficult (Achugar and Schleppegrell 2005; Coffin 2004), they can also enable authors to convey cause across the narrative (Tapiero et al. 2002), expressing causation between sentences and even between paragraphs. Indeed, the more nonlinear a narrative, the more likely it is that causation will be less direct (Coffin 2004, 2006). A historical narrative's many actors, participants, situations, and circumstances reduce the likelihood that any one antecedent truly caused any one consequence. Thus, cohesion is one way that authors imply causal relationships across historical contexts (Beck et al. 1989). For example, readers might recognize a causal connection between how the colonists rebelled against increased British taxes and the way that farmers reacted during the Whiskey Rebellion shortly after the American Revolution. While textbook authors might not make such a connection explicit, the similarities between these events suggest a causal relationship. By helping students to map connections across time, teachers enable students to identify cohesive causal connections and make them more explicit (Rogers 2011).

\section{Causal Asyndetic Constructions (CACs)}

In contrast to the macro-level cohesive causal connections, CACs function between two clauses in a text; in these cases, authors could have chosen to employ causal connectors but did not. Specifically, CACs imply causation between two sequentially proximal sentences without an explicit link that would indicate such a relationship (Fitzgerald 2012).

For example, one middle school history textbook writes of the rise of plantations in the lower United States, "Small landowners with just one or two slaves simply could not compete. Many gave up their land and moved westward" (Garcia et al. 2005, p. 105). There is an implied causal relationship between these two sentences. The small landowners moved west because they could not compete with the plantation owners. 
The authors could have used a conjunction to explicitly connect these two sentences but they did not. Indeed, there are no connectors or explicit causal markers that illustrate cause-effect, though it is certainly implied. Since the relationship is not explicit, one cannot say that event ' $\mathrm{e}$ ' directly caused result ' $r$.' Rather, a causal relationship is recognized between the two sentences by what is implicitly understood from the discourse.

The implied causal relationship between sentences such as these influences each sentence's meaning-potential. On the one hand, the asyndetic sentences above are grammatically correct; they are independent of one another and stand alone as coherent thoughts. Since they exist independently and are located next to each other in the text, yet are not connected by any overt signals, these sentences are paratactic (equal in semantic weight). On the other hand, the "effect" sentence (the second one, in this case) does not exist independently from the first. As the above example illustrates, the small landowners would not have given up their land if they could have competed against the plantation owners. Conceptually, these sentences are hypotactic - one is subordinate to the other. Asyndetic constructions, then, are both paratactic and hypotactic in nature; grammatically, they are independent sentences but semantically one is subordinate to the other. Without explicit connectors, however, the hypotactic relationships are not signaled, sometimes making it difficult to determine the intended relationship between two sentences and certainly making it difficult to teach readers to make those contextual decisions. As Achugar and Schleppegrell (2005) note, "understanding the role of juxtaposition in the construction of causal reasoning and being able to recover the implicit connections is important for student readers" (p. 311). With regards to CACs, understanding the ways in which some juxtaposed sentences implicitly express causation is important to students' comprehension, leading to better historical thinking within the history classroom.

Gohl (2000) identified three linguistic signals associated with speakers' use of asyndetic constructions. By analyzing an adult, native-German speaker corpus, she determined that (1) prosodic design, (2) sequential proximity, and (3) modal particles all signaled asyndetic constructions. Of these three, prosodic design is not relevant to this current discussion because it examines how the intonation of what is being said effects the meaning of the statement. Here, written text is being examined. Sequential proximity is equally unhelpful when analyzing history textbooks because sentence proximity does not necessitate CACs, although it is a condition. Modal particles, however, may be relevant to identifying and explaining CACs in history textbooks.

Modality can be explored as a signal for CACs in history textbooks because it indicates the probability or "usuality" of propositions (Halliday and Matthiessen 2004). A historical actor's potential, probable, or usual action may influence his/her reality within the text. For example, the potential of success is an important consideration in determining whom a group should ally with, as in "Without French help, the Native Americans could not stop

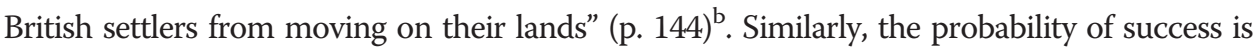
a consideration; "[Destroying British boats] would cut off British communications with Charles Town" (Garcia et al. 2005, p. 191). In both cases, modals realizing potentiality (e.g., could) and probability (e.g., would) encourage authors to explain why a particular event either turned out positively or negatively for a particular actor.

Although they have been identified in history textbooks, the frequency with which and the ways in which CACS are used have not been examined. This information 
would enable history educators to better understand if they should focus instructional time towards teaching students to identify them and, if so, how they might explain these implied constructions.

\section{Design and method}

In examining CACs in United States history textbooks, two questions were explored: (1) Do CACs occur in history textbooks with similar frequency to causal conjunctions and causal material processes (CMPs)? and (2) How is causal asyndetic cohesiveness signaled in history textbooks? In order to examine the role that these constructions play in the history textbook genre, two middle school and two high school United States history textbooks were selected. Informed by Coffin's (2006) study of school history genres, secondary education texts were selected because causation is most likely to be expressed in texts designed for this developmental level. Causal explanations are sometimes lacking in the biographical, autobiographical and historical recount genres used in elementary social studies texts. Furthermore, United States history is the most often taught social studies topic in the United States (Evans 2004), making an analysis of secondary United States history textbooks practically important.

Since secondary education covers a wide range of student cognitive and developmental capabilities, engaging students age 12 years to 18 years old, two middle school and two high school textbooks were analyzed. Using texts designed for students across this age range provides a perspective on linguistic structures in which a variety of students might engage. For consistent analysis, the content of the texts remained comparable because the subject of the texts were the same, even if the linguistic demands of the texts differed.

Two historical topics were selected for analysis from each text: (1) the American Revolution and (2) the Civil War. All four textbooks included sections about these topics and the chronological nature of the US History narrative was similar for each. These two topics were selected because they are ones to which students across the United States are frequently exposed. Thus, analysis of these topics holds an ecological relevance for instruction and learning in the K-12 history classroom.

Only main-text sentences were analyzed within the selected texts to decrease interpretive effects from paratext (charts, pictures, and primary source information). Direct quotations within the main texts were also disregarded, as were any connections made between the direct quotation and the sentences preceding and following the quotation. These decisions were made in an effort to better understand the constructions as written by the textbook authors and editors without the added syntactic and semantic difficulty of integrating the thoughts of historical figures.

Prior to analysis, possible CACs were identified and extracted from these selections. Once extracted, a broad "because and so" test was adopted to verify the causal relationship (Meyer 2000) and to determine the direction of the causal expression (cause-to-effect or effect-to-cause) (Noordman and de Blijzer 2000; Sanders 2005). In other words, if it was logically possible to insert the words because or so between any two, sequential sentences that lacked causal markers, the construction was labeled 'causally asyndetic'.

In order to compare the frequency of CACs with other more frequently studied forms of causal expression, CMPs realized by verbs such as made and forced (e.g., 
"Grant's maneuver made Lee surrender", "Lee forced Grant to retreat", etc.) and casual conjunctions (e.g., "Lee surrendered because of Grant's maneuver", "Lee's forces overwhelmed Grant so he retreated", etc.) were identified within each history textbook. Frequency data was recorded and percentages per total number of words were calculated. Two chi-square analyses were also conducted to compare the frequency of CACs (1) between the texts and (2) within their grade-level categories, providing a description of how often they were used per authors and per grade-level.

Following these quantitative analyses, the CACs culled from the textbooks were qualitatively analyzed. Analysis began with Gohl's (2000) findings about cohesive signals in verbal protocols; the use of modality in the asyndetic constructions was examined. Next, cases that remained were analyzed, focusing on the experiential processes construed by the textbook authors. Additional coding categories included mental, relational, and verbal processes.

\section{Findings}

A mixed-methods analysis of four United States history textbooks demonstrated that CACs occur as frequently, if not more frequently, than other more explicit forms of causation. In addition, CACs can be explained via mental, relational, and verbal processes or by modals, which can function similarly to these processes.

\section{Do CACs occur in history textbooks with similar frequency to causal conjunctions and causal material processes?}

The frequency with which causal constructions occur in United State history textbooks seems considerably less than their overall importance as a meaning-making structure. As Table 1 illustrates, both explicit (CMPs and conjunctions) and implicit (CACs) means of expressing causation are few in comparison to the total number of words per passage. Indeed, verbs such as forced, caused, and led were found in constructions such as "They helped to force France and Britain to aid the Confederate cause" (Garcia et al, 2005, p. 468) and "This scream, later called the "rebel yell", caused the Union troops to panic" (Garcia et al, 2005, p. 469). These verbs realized material processes that made causation explicit for the reader. Causal conjunctions (e.g., because and so) were used in instances such as "Most children were taught to read so that they could understand the Bible" (Garcia et al, 2005, p. 121). Using the methods described above, multiple forms of CACs were identified. Nevertheless, the data show that CACs occur in all four texts with similar, if not greater, frequency than the combined number of causal

Table 1 Frequency of causal constructions per textbook

\begin{tabular}{cccccc}
\hline Textbook & $\begin{array}{c}\text { Level of } \\
\text { school }\end{array}$ & $\begin{array}{c}\text { Causal material } \\
\text { processes }\end{array}$ & Conjunctions & $\begin{array}{c}\text { Causal asyndetic } \\
\text { constructions }\end{array}$ & $\begin{array}{c}\text { Total number of words } \\
\text { in passages }\end{array}$ \\
\hline Holt & High & $15(.26 \%)$ & $14(.24 \%)$ & $18(.31 \%)$ & 5,720 \\
$\begin{array}{c}\text { McGraw } \\
\text { Hill }\end{array}$ & High & $33(.20 \%)$ & $11(0 \%)$ & $28(.17 \%)$ & 16,436 \\
$\begin{array}{c}\text { Prentice } \\
\text { Hall }\end{array}$ & Middle & $35(.24 \%)$ & $13(0 \%)$ & $37(.25 \%)$ & 14,531 \\
$\begin{array}{c}\text { McDougal } \\
\text { Little }\end{array}$ & Middle & $46(.25 \%)$ & $38(.21 \%)$ & $52(.28 \%)$ & 18,450 \\
\hline
\end{tabular}


conjunctions and CMPs. Asterisks indicate that the number of tokens in a particular category comprise less that $.001 \%$ of those in the sample.

Although there are differences between the total numbers of causal constructions expressed by any particular textbook, the percentage of tokens in each category is fairly consistent. For example, although differences were observed between instances of CMPs in the Holt and McDougal Little texts, their relative percentage of use per word is similar. These similarities occur not only within categories but between texts as well. Excluding the obvious outliers for $0 \%$ in the causal conjunctions category, the median percentage for frequency of use in all categories is $.245 \%$ with a range from $.17 \%$ to $.31 \%$. The percentages appear consistent amongst causal constructions and across texts.

CACs often occur more frequently than either CMPs or conjunctions as individual causal constructions within the sample. In only one case did the use of verbs realizing a CMP occur more frequently than CACs; there were five more instances of CMPs than CACs in the McGraw Hill text. In addition, textbook authors consistently used CACs more often than causal conjunctions. Again, though, this difference in frequency is not great $(<.05 \%)$; no one form of causal expression is used with much greater frequency than another.

Disaggregating the data illustrates the distribution of these frequencies. Table 2 illustrates that the passages about the American Revolution express causation asyndetically more often than the Civil War passages. The latter passages use more CMPs. The results illustrated in Table 2 are not consistent throughout the textbooks.

Like the cumulative data, the disaggregated data does not appear to follow any particular distribution pattern. A chi-square test for independence analysis confirms this observation. There is no significant relationship between text and causal expression, $\mathbf{c}^{2}$ $(6, N=329)=9.22, p=.05$. The authors' use of CMPs, causal conjunctions, and CACs is similar across all texts.

Categorizing these texts into grade-level pairs yields a similar result. Again, there is no significant relationship between the grade-level of the text and the use of causal expression, $\mathbf{c}^{2}(2, N=329)=1.15, p=.05$. The distribution of causal expressions in middle school texts is similar to the distribution in high school texts.

CMPs, causal conjunctions, and CACs are distributed similarly across all four textbooks. In three of the four textbooks, CACs are used more frequently than either

Table 2 Frequency of causal constructions per textbook passage

\begin{tabular}{|c|c|c|c|c|}
\hline Textbook passage & $\begin{array}{l}\text { Causal material } \\
\text { processes }\end{array}$ & Conjunctions & $\begin{array}{c}\text { Causal asyndetic } \\
\text { constructions }\end{array}$ & $\begin{array}{c}\text { Total words per } \\
\text { passage }\end{array}$ \\
\hline $\begin{array}{l}\text { Holt - American } \\
\text { Revolution }\end{array}$ & $10(.39 \%)$ & $10(.39 \%)$ & $8(.31 \%)$ & 2,589 \\
\hline Holt - Civil War & $5(.16 \%)$ & $4(.13 \%)$ & $10(.32 \%)$ & 3,131 \\
\hline $\begin{array}{l}\text { McGraw-Hill - American } \\
\text { Revolution }\end{array}$ & $13(.17 \%)$ & $4(0 \%)$ & $20(.25 \%)$ & 7,861 \\
\hline McGraw-Hill - Civil War & $20(.23 \%)$ & $7(0 \%)$ & $7(0 \%)$ & 8,575 \\
\hline $\begin{array}{l}\text { Prentice Hall - American } \\
\text { Revolution }\end{array}$ & $11(.12 \%)$ & $7(0 \%)$ & $22(.25 \%)$ & 8,962 \\
\hline Prentice Hall - Civil War & $24(.43 \%)$ & $6(.11 \%)$ & $9(.16 \%)$ & 5,569 \\
\hline $\begin{array}{l}\text { McDougal Little - } \\
\text { American Revolution }\end{array}$ & $25(.24 \%)$ & $22(.22 \%)$ & $28(.27 \%)$ & 10,207 \\
\hline McDougal Little - Civil War & $21(.25 \%)$ & $16(.19 \%)$ & $20(.24 \%)$ & 8,243 \\
\hline
\end{tabular}


CMPs or causal conjunctions, although this is dependent on the particular historical topic. When not the more frequently used constructions, CACs are the second most frequently used.

\section{How is causal asyndetic cohesiveness signaled in history texts?}

Gohl (2000) noted that modality signals asyndetic constructions in verbal discourse. Her findings serve as a point of departure for this qualitative analysis. Indeed, as illustrated in Table 3, 13\% of CACs identified in the selected passages contained modals. An author's choice of could or would realize a circumstantial potential by which historical actors make decisions.

\section{Modality}

Ascribing potential agency to historical events allows textbook authors to make causal connections between events. In history texts, the modal could realizes the potential of an actor, group of actors, or event to change a circumstance. For example, the impact of the Tea Act on the colonial economy are explained as: "The Tea Act refunded fourfifths of the taxes the company had to pay to ship tea to the colonies, leaving only the Townshend Tax. East India Company tea could now be sold at lower prices than smuggled Dutch tea" (Appleby et al. 2000, p. 65). Prior to this passage, the East India Company was struggling to match the prices of the tea that was being smuggled into the colonies.

The potential for lower prices, as indicated by could, was a direct result of the Tea Act. The Tea Act and lower prices did not happen in isolation from each other. If they had, the authors might have written, "The Tea Act refunded four-fifths of the taxes the company had to pay to ship tea to the colonies. East India Company tea sold at a lower price than smuggled tea." This alternative construction would have indicated a temporal relationship; the juxtaposition of these sentences suggests then might be an appropriate connector. Rather, through the inclusion of could, the authors indicate that the British Parliament was acting for the benefit of the East India Company, providing a potential situation that they could exploit for profit and implying a causal relationship.

The use of would also indicates a causal relationship. This modal, however, expresses the predictive likelihood of a situation as in, "Although he failed to capture Petersburg, a rail center south of Richmond, he began a siege of the city. This siege would cut supplies to the Confederate capital" (Ayers et al. 2009, p. 130). General Grant, the "he" in the passage, predicted that isolating Richmond's main supply railway would likely starve the city of supplies. Thus, he first tried to capture Petersburg; failing that, he laid siege

Table 3 Distribution of signals for causal asyndetic constructions

\begin{tabular}{cccccc}
\hline Texts & Modality & $\begin{array}{c}\text { Mental } \\
\text { process }\end{array}$ & $\begin{array}{c}\text { Relational } \\
\text { process }\end{array}$ & $\begin{array}{c}\text { Verbal } \\
\text { process }\end{array}$ & $\begin{array}{c}\text { Total \# of asyndetic } \\
\text { constructions }\end{array}$ \\
\hline Holt & $3(17 \%)$ & $8(44 \%)$ & $5(28 \%)$ & $2(11 \%)$ & 18 \\
McGraw-Hill & $6(21 \%)$ & $20(71 \%)$ & $2(7 \%)$ & $0(0 \%)$ & 28 \\
Prentice Hall & $1(3 \%)$ & $21(53 \%)$ & $13(35 \%)$ & $2(5 \%)$ & 37 \\
$\begin{array}{c}\text { McDougal } \\
\text { Little }\end{array}$ & $7(13 \%)$ & $29(56 \%)$ & $13(25 \%)$ & $3(6 \%)$ & 52 \\
All Texts & $17(13 \%)$ & $78(58 \%)$ & $33(24 \%)$ & $7(5 \%)$ & 135 \\
\hline
\end{tabular}


to the city. Grant's actions were not based on fact, for he did not know if the siege would affect the supply lines into Richmond. By using would, the authors suggest that Grant's actions were based on a predicted result. Otherwise, they might have written, "This siege cut supplies to the Confederate capital", suggesting an explicit causal connection.

Across all four texts, modality: potential were used more frequently than modality:predictive. Of the eleven instances of potentiality, two specific modals were used: could and might. In contrast, only one predictive modal, would, was used in six instances. Thus, while both types of modals are used to form the same implied causal construction, modality:potentiality were expressed by more variant structures than modality: predictive.

\section{Processes}

More commonly than modals, however, CACs were constructed by using specific verbs to realize non-material processes, such as mental, verbal, and relational processes. In these cases, authors' used one or more verbs to construe "a quantum of change in the flow of events taking place in our own consciousness" (Halliday and Matthiessen 2004, p. 197). These "quantums of change" explained either the antecedent ("cause") or consequence of the implied cause-effect relationship, often by describing a historical actors' internal state. That is, by explaining a historical actors' mind-set, condition, or claims, authors were able to imply the reason for a consequent action. Specifically, mental [e.g., "Soon after Washington's return, the British government decided it had to push the French out of the Ohio River valley. In 1755, it sent General Edward Braddock to Virginia with orders to capture Fort Duquesne" (Davidson and Stoff 2007, p. 142)], relational [e.g., "The Battle of Quebec was the turning point of the war. When Montreal fell the next year, all of Canada was in British hands" (Garcia et al. 2005, p. 134)], and verbal processes [e.g., "With their assemblies outlawed, some colonists refused to pay taxes. They said that being taxed without having a voice in government violated their rights" (Garcia et al. 2005, p. 147)] were used to imply such causation. Each of these instances will be explained below and, in certain cases, contrasted with other processes concurrently identified in the texts.

\section{Mental processes}

Rather than causally relating events through physical action, mental processes enable authors to connect historical events to historical actors' mind-sets. While mental processes are internal to an individual or group, they can be illustrated in causal relationships, similar to the ways in which cause is realized through modality. Indeed, Halliday and Matthiessen (2004) argued that mental processes can serve as "metaphors of modality" (p. 208), since they illustrate internal potential for external action. In other words, "sensing" accounts for historical actors' potential or predictive actions. Four types of sensing signal CACs involving mental processes: cognition, emotion, desire, and perception (Table 4).

\section{Cognition}

Processes of cognition describe historical actors' thoughts, motivating particular actions. For example, when discussing General Braddock's attack on the French at Fort 
Duquesne prior to the French and Indian War, textbook authors wrote, "Soon after Washington's return, the British government decided it had to push the French out of the Ohio River valley. In 1755, it sent General Edward Braddock to Virginia with orders to capture Fort Duquesne" (Davidson and Stoff 2007, p. 142). By constructing these sentences in this way, the authors signal that the British government, the actor in the first sentence, intentionally ordered Braddock to capture Fort Duquesne, following Washington's defeat. The reason for the British government's decision is realized in its role as sensor of cognition. The cognition of the British government "caused" Braddock's attack on Fort Duquesne, signaling readers to the implied causal connection.

\section{Emotion}

Processes of cognition are not the only mental processes that were used to signal CACs, however. The authors also used emotive processes to explain why events occurred, as illustrated by "feared" in "Many leading merchants and large landowners were Loyalists. They feared a rebellion would lead to a change in government and that they would lose their property" (Davidson and Stoff 2007, p. 157). Rather than the cognitive mental process used to describe the British government's action, this CAC relies on the emotive power of "fear" to describe a causal relationship between the merchants' reality and possible outcomes of rebellion in the colonies. Strong emotions such as "fear" elicit action (or reaction), implying a causal relationship between the antecedent and the consequence.

\section{Desideration}

In addition to mental process CACs expressing emotive causation, textbook authors also used desideration to imply causal links. Rather than using emotions to signal causal connections, desideration verbs such as "want" and "hope" allow authors to tie causal events to an actor's desires. For example, to describe the desired result of the post-Boston Tea Party conciliation, Garcia et al. (2005) wrote, "Britain rejected the offer. It not only wanted repayment but it also wanted the men who destroyed the tea to be brought to trial" (p. 151). Rather than expressing an emotion or a thought, Britain is portrayed as having a desire. The specifics of this desire, as explained in the second sentence, are predictive of the result, a rejection of the colonists' peace. Thus, the wants and hopes of historical actors play a role in detailing the reasonableness of their actions and explain the cause of their decisions.

\section{Perception}

Yet another example of how various mental processes can be used to signal causation is in the use of perception. Often, perception is directly experiential; seeing, hearing,

Table 4 Frequency of use for four types of mental process causal asyndetic constructions

\begin{tabular}{ccccc}
\hline Textbook & Cognition & Emotion & Desideration & Perception \\
\hline Holt & 9 & 8 & 10 & 2 \\
McGraw Hill & 4 & 2 & 1 & 1 \\
Prentice Hall & 9 & 7 & 3 & 2 \\
McDougal Little & 15 & 4 & 1 & 0 \\
Total & 37 & 21 & 15 & 4 \\
\hline
\end{tabular}


feeling, etc. are all processed by the brain directly from real-world experience. Indeed, these direct experiences can cause action. Individual actors can also metaphorically sense, however, as in "Most of the British army was in New York, and New York saw that as an unfair burden. Its assembly refused to pay to house the troops" (Garcia et al. 2005, p. 147). The authors used "saw" to blur the boundaries between perception and cognition; the State of New York did not see an unfair burden. Yet, the authors use this verb metaphorically to convey perception and signal a causal connection. By "seeing" the reality of the political and economic situation, New York was enabled to justifiably refuse the quartering of troops.

\section{Relational processes}

Besides mental processes (and the four types of sensing), relational processes were also used to imply causation. Relational processes signal causal asyndetic cohesiveness because they make claims for which the authors must account in their explanations. Using identifying verbs such as is, represents, and means, authors create a Token/Value relationship in one clause/sentence. Another clause/sentence is often needed to explain that relationship, implying causation.

For example, Garcia et al. (2005) described the Battle of Quebec this way: "The Battle of Quebec was the turning point of the war. When Montreal fell the next year, all of Canada was in British hands" (p. 134). The Battle of Quebec [token] represents the turning point [value] and this claim needs substantiation; historical turning points are in frequent debate. Here, the authors choose to employ a CAC to explain their claim, implying Montreal's related fall to the British as a significant political and military consequence of the Battle of Quebec.

\section{Verbal processes}

Still a third process was used to signal implicit causal connections, verbal processes. Although they only comprised a small percentage of the total CACs found amongst the text samples, verbal process CACs served a specific purpose in the selected texts; all instances of CACs signaled by verbal processes were related to the speech of historical actors. For example, following the dispute between the colonists and the British government over taxation, the colonists began refusing to pay taxes: "With their assemblies outlawed, some colonists refused to pay taxes. They said that being taxed without having a voice in government violated their rights" (Garcia et al. 2005, p. 147). In cases such as this, the authors blur the lines between citation and cognition. There is no documentation, for example, that the colonists said those words. Rather, it is more likely that the colonists generally thought that taxation without representation was unfair. Like the example of CAC signaled by cognitive mental process above, then, these verbal process CACs use the link between thought and action to imply causal relationships between events.

\section{Summary}

Figure 1 illustrates the delicacy of the CACs found within the textbook passages. The numbers following each category indicate the frequency with which they occurred. Textbook authors used modality to construct implied causal relationships, like Gohl 


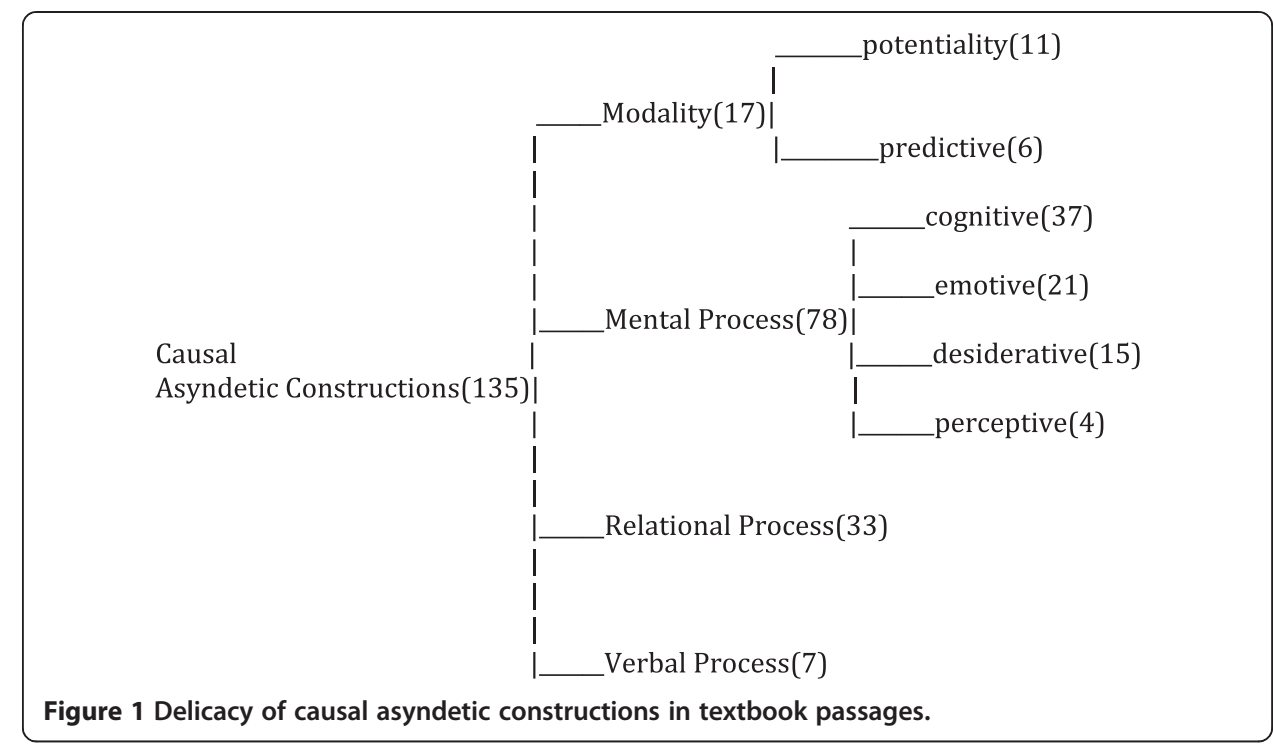

(2000) found in her verbal discourse analysis. In addition, mental, relational, and verbal processes were also used to form CACs, signaling implied causal relationships. Mental process CACs far outnumber other types, accounting for $58 \%$ of the total. Indeed, one subtype from this category, cognition, had more tokens than any of the three major types of CACs.

\section{Discussion}

Textbooks express causation using a variety of explicit and implicit means. Authors frequently use CMPs and conjunctions to explicitly express causation (Achugar and Schleppegrell 2005). In addition, they also use CACs to imply causation (Fitzgerald 2012). This study demonstrates that CACs are used as frequently, if not more frequently, than CMPs and causal conjunctions in sample United States history textbooks. Such causation is signaled through the use of modality, mental processes, relational processes, and verbal processes.

\section{Possible reasons for causal asyndetic constructions}

There are four possible explanations for why history textbook authors employ CACs. One reason relates to historical content. History textbook authors intentionally develop unified, nation-state narratives free of contentious views (FitzGerald 1979; Moreau 2004; O'Leary 1999; Zimmerman 2002). No matter how unified (some say "whitewashed") these narratives are, however, conflict amongst historical interpretations cannot always be completely ironed out of the narrative. Whether because of (1) a lack of historical evidence, (2) varied interpretations, (3) political sensibilities, or (4) a combination thereof, relationships between historical events are not always clear. Thus, there are times when textbook authors surely have to hedge, making implied causal links rather than explicit ones.

For example, it seems logical that General Grant laid siege to Petersburg because he wanted to cut Confederate supply lines, but this is only one possible explanation. $\mathrm{He}$ might have also thought that President Lincoln would fire him if he withdrew his 
forces, as Lincoln did earlier with General McClellan. Unless textbook authors have evidence to support the implied causal connections, which they rarely provide, CACs may be a symptom of insufficient historical evidence.

It could also be the case that the frequency of casual asyndetic constructions is higher in texts like history textbooks, where authors are forced to condense many historical facts into a specified space; indeed, textbook authors have often complained about such constraints (cf. Brinkley et al. 2005). If this is the case, CACs may be a phenomenon of condensing causal cohesive ties that would normally be spread across a wide textspace. In other words, textbook authors may use CACs in the constrained space of the textbook when they would normally explain how a causal relationship developed between events over a paragraph or chapter.

A third reason why textbook authors employ CACs relates to authorial voice and interpretation. Indeed, it is possible that authors use CACs to add their own voice to texts traditionally admonished for not displaying the interpretive nature of history (Apple 2000; Epstein 1994; Loewen 1995). When authors use CACs, they signal to readers that the causal relationship between two events is not direct. Rather, as demonstrated in this study, many of the CACs refer to a historical actor's internal mind, something probably not known to too many authors. Thus, authors may intentionally use these constructions to approximate interpretive dialogue with readers.

Yet a fourth explanation might simply be that CACs are a common discourse feature in history texts. This study is limited to a small sample of history textbooks; it is certainly possible that other historical narratives routinely use CACs as well. The use of CACs in history texts might be just one example of the many ways that language can be used to convey meaning, specifically causation. Explorations into other forms of historical narratives might confirm this explanation.

These explanations are not mutually exclusive, either. The use of CACs in history textbooks may be a symptom of a combination of these reasons. Unfortunately, both possibilities were outside the scope of this study. Interviews with textbook authors may help to clarify why CACs are used. In addition, further studies examining CACs in a larger sample of United States history textbooks, other school-based texts, and other historical narratives may clarify their communicative purpose.

\section{Implications for teaching}

Since CACs only imply causation, readers must infer the relationship between the sentences. If the relationship is inferred incorrectly, a reader's comprehension of the passage will suffer. Reading research suggests that a reader's ability to make the correct inference is related to his/her general ability as a reader (Beck et al. 1989; McKeown et al. 1992; McNamara et al. 1996). That is, better readers will probably make the inferences intended by the author; poorer readers might not. In order to help all students comprehend historical texts better, teaching students to identify and explain how causation is constructed may help their comprehension and writing.

In addition to teaching students to identify causal conjunctions (Williams et al. 2007) and CMPs (Achugar and Schleppegrell 2005; Schleppegrell et al. 2004), these data demonstrate that United States history teachers should also teach students how to identify and make meaning from CACs; CACs account for a large number of total causal 
constructions in United States history textbooks. In doing so, teachers will enable students to comprehend and create a wider variety of causal relationships.

In order to teach students to recognize CACs, teachers can use three explanations. Teachers might first want to begin by explaining how CACs are developed through mental and verbal processes, since these make up the majority of CACs. Instructing students to pause whenever an author suggests that a historical actor thought, felt, or said something and look for ways in which those thoughts and feelings may have impacted historical events, students will be able to better recognize implied causal relationships between individual psychologies and physical events.

Similarly, teachers might suggest that students pause whenever they encounter modals. This approach marries the "look for" approach advocated for teaching causal conjunctions and the "look around" approach one might use for comprehending mental and verbal process CACs. When students encounter words like would or could, they should ask themselves if the possibility implied in that clause was realized in a physical action. If so, then it is likely that a CAC is present.

Relational process CACs may be the most difficult to explain because students must understand the Token/Value relationship between events; another way of explaining this relationship might be through the Claim/Evidence relationship between ideas. Helping students to understand that Token/Value relationships must be supported by evidence is both important for their understanding as well as their writing. Intentionally asking students to identify claims within a text might help them to explore how causal relationships support Token/Value relations.

\section{Conclusion}

As this study illustrates, the ways in which causation is expressed in history textbooks extends beyond the causal conjunctions and CMPs so often used to teach students how causation is expressed. Although these more explicit forms are important, teachers must understand the ways in which processes are realized within the text structure, sometimes signifying a causal connection, since these causal structures occur frequently within history textbooks. In order to enact such instruction, history teachers in particular need to understand the disciplinary ways in which language constructs meaning (Coffin 2004; Schleppegrell 2004), illustrated through this study's examples. Findings suggest that history teachers' focus on content area literacies needs to extend beyond techniques for understanding the words in a particular text to explore the ways in which language realizes meaning.

\section{Endnotes}

${ }^{a}$ Although Achugar and Schleppegrell (2005) do not refer to the causal process verbs in their study as Causal Material Processes (CMPs), all of the verbs used in the more explicitly causal passages in this study realized material processes (e.g., forced and make). I use the term CMP throughout this paper to differentiate the more explicit material processes from the more implicit processes that construct causal asyndetic constructions (CACs), explained later in this study.

${ }^{\mathrm{b}}$ Unless otherwise noted, all italicized words within direct quotes are added for emphasis and clarity of explanation. 


\section{Abbreviations}

CAC: Causal asyndetic construction; CMP: Causal mental process.

\section{Competing interests}

The author declares that he has no competing interests with regards to this work.

\section{Author's contributions}

JCF is solely responsible for conceiving this study, collecting texts, coding samples, conducting the proper analyses, and writing this manuscript.

\section{Author's information}

JCF is an assistant professor in Wagner College's Department of Education. He teaches pre-service social studies teachers, where he routinely helps them select texts from which to teach US history content.

\section{Acknowledgements}

N/A

Received: 12 September 2013 Accepted: 8 November 2013

Published: 10 April 2014

\section{References}

Achugar, M, and MJ Schleppegrell. 2005. Beyond connectors: The construction of cause in history textbooks. Linguistics and Education 16: 298-318.

Apple, MW. 2000. Official knowledge: Democratic education in a conservative age. New York: Routledge. Appleby, J, A Brinkley, and JM McPherson. 2000. The American journey: Building a nation. Columbus: Glencoe. Ayers, EL, RD Schulzinger, JF De La Teja, DG White, and SS Wineburg. 2009. American Anthem. Orlando: Holt, Rinehart, and Winston.

Beck, IL, MG McKeown, and EW Gromoll. 1989. Learning from social studies texts. Cognition and Instruction 6(2):99-158. Blettner, E. 1983. One made many and many made one: The role of asyndeton in Aristotle's rhetoric. Philosophy and Rhetoric 16(1):49-54.

Brinkley, A, GJ Kornblith, and C Lasser. 2005. The challenges and rewards of textbook writing: An interview with Alan Brinkley. The Journal of American History 91(4):1391-1397.

Carr, EH. 1961. What is history? New York: Vintage Books.

Ciardiello, AV. 2002. Helping adolescents understand cause/effect text structure in social studies. Social Studies 93(1):31.

Coffin, C. 2004. Learning to write history: The role of causality. Written Communication 21(3):261-289.

Coffin, C. 2006. Historical discourse: The language of time, cause, and evaluation. London: Continuum.

Davidson, JW, and MB Stoff. 2007. America: History of our nation. Boston: Pearson Prentice Hall.

Epstein, TL. 1994. American revised revisited: Adolescents' attitudes towards a United States history textbook. Social Education 58(1):41-44.

Evans, RW. 2004. Social studies wars: What should we teach the children? New York: Teachers College Press.

FitzGerald, F. 1979. America revised. Boston: Little, Brown, and Company.

Fitzgerald, JC. 2009. Textbooks and primary source analysis. Social Studies Research and Practice 4(3). http://www. socstrpr.org/?page_id=866. Accessed 6 September 2013.

Fitzgerald, JC. 2011. Comprehending historical narratives: Exploring the relationship between causal language and students' mental representations of history, Unpublished Dissertation. University of Pittsburgh.

Fitzgerald, JC. 2012. "It doesn't say": Exploring students' understandings of asyndetic constructions in history textbooks. Social Studies Research and Practice 7(3). http://www.socstrpr.org/?page_id=2273. Accessed 6 September 2013.

Garcia, J, DM Ogle, C Frederick Risinger, J Stevos, and WD Jordan. 2005. Creating America: A history of the United States. Evanston: McDougal Little.

Gohl, C. 2000. Causal relations in spoken discourse: Asyndetic constructions as a means for giving reasons. In Cause-Condition-Concession, ed. E Couper-Kuhlen and B Kortmann, 83-110. Berlin: Mouton de Gruyter.

Halliday, MAK, and CMIM Matthiessen. 2004. An introduction to functional grammar. London: Hodder Education.

Kemp, R. 2011. Thematic or sequential analysis in causal explanations? Investigating the kinds of historical understanding that Year 8 and Year 10 demonstrate in their efforts to construct narratives. Teaching History 145:32-43.

Levesque, S. 2008. Thinking historically: educating students for the twenty-first century. Toronto: University of Toronto Press.

Loewen, JW. 1995. Lies my teacher told me: Everything your American history textbook got wrong. New York: Touchstone.

Lyda, A. 2006. Asyndetic subordination in interpreting: The case of concessive markers. In Innovations in psycholinguistics: A step to Innovations in brain, culture, cognition, and communication research, ed. E Brosig. Vienna: TRANS: Internet-Zeitschrist fur Kulturwissenschaften.

McKeown, MG, IL Beck, GM Sinatra, and JA Loxterman. 1992. The contribution of prior knowledge and coherent text to comprehension. Reading Research Quarterly 27(1):79-93.

McNamara, DS, E Kintsch, NB Songer, and W Kintsch. 1996. Are good texts always better" Interactions of text coherence, background knowledge, and levels of understanding in learning from text. Cognition and Instruction 14(1):1-43.

Meyer, PG. 2000. The relevance of causality. In Cause-Condition-Concession, ed. E Couper-Kuhlen and B Kortmann, 9-34. Berlin: Mouton de Gruyter.

Meyer, BJF, and LW Poon. 2001. Effects of structure strategy training and signaling on recall of text. Journal of Educational Psychology 93(1):141-159. 
Meyer, BJF, DM Brandt, and GJ Bluth. 1980. Use of top-level structure in text: Key for reading comprehension of ninth-grade students. Reading Research Quarterly 16(1):72-103.

Moreau, J. 2004. Schoolbook nation: Conflicts over American history textbooks from the Civil War to the present. Ann Arbor: The University of Michigan Press.

Moss, B. 2005. Making a case and a place for effective content area literacy instruction in the elementary grades. Reading Teacher 59(1):46-55.

Muller, WG. 1991. The emotional asyndeton in the literature of feeling, Anglistentag 1991 Dusseldorf Proceedings, 143-158. Nokes, JD. 2010. Observing history teachers' literacy related decisions. Theory and Research in Social Education 38(4):515-544. Noordman, LGM, and F de Blijzer. 2000. On the processing of causal relations. In Cause-Condition-Concession, ed. E Couper-Kuhlen and B Kortmann, 35-56. Berlin: Mouton de Gruyter.

Novick, P. 1988. That noble dream: The "objectivity question" and the American historical profession. New York: Cambridge University Press.

O'Leary, CE. 1999. To die for: The paradox of American patriotism. Princeton: Princeton University Press.

Rogers, R. 2011. "Isn't the trigger the thing that sets the rest of it on fire? Causation maps: Emphasizing chronology in causation exercises. Teaching History 142:50-55.

Rosette, F. 2009. Translating asyndeton from French literary texts into English. Target 21(1):98-134.

Sanders, TJM. 2005. Coherence, causality, and cognitive complexity in discourse. http://w3.erss.univ-tlse2.fr:8080/index jsp?perso=bras\&subURL=sem05/proceedings-final/03-Sanders.pdf. Accessed 6 September 2013.

Schleppegrell, MJ. 2004. The language of schooling: A functional linguistics perspective. New York: Routledge.

Schleppegrell, M, and M Achugar. 2003. Learning language and learning history: A functional linguistics approach. TESOL Journal 12(2):21-27.

Schleppegrell, M, M Achugar, and T Oteiza. 2004. The grammar of history: Enhancing content-based instruction through a functional focus on language. TESOL Quarterly 38(1):67-93.

Tapiero, I, P van den Broek, and M-P Quintana. 2002. The mental representation of narrative texts as networks: The role of necessity and sufficiency in the detection of different types of causal relations. Discourse Processes 34(3):237-258.

Trabasso, T, and P van den Broek. 1985. Causal thinking and the representations of narrative events. Journal of Memory and Language 24:612-630.

Trabasso, T, T Secco, and P van den Broek. 1984. Causal cohesion and story coherence. In Learning and Comprehension of Text, ed. H Mandl, NL Stein, and T Trabasso, 83-111. Hillsdale: Lawrence Erlbaum Associates. VanSledright, B. 2002. In search of America's past. New York: Teachers College Press.

Veel, R, and C Coffin. 1996. Learning to think like an historian: The language of secondary school history. In Literacy in Society, ed. R Hasan and G Williams, 191-231. New York: Addison Wesley Longman.

Waring, S. 2010. Escaping myopia: Teaching students about historical causality. The History Teacher 43(2):283-288.

Warren, WH, DW Nicholas, and T Trabasso. 1979. Event chains and inferences in understanding narratives. In New Directions in Discourse Processing, ed. RO Freedle, 23-52. Norwood: ABLEX Publishing Company.

Williams, JP, AM Nubla-Kung, S Pollini, KB Stafford, A Garcia, and AE Snyder. 2007. Teaching cause-effect text structure through social studies content to at-risk second graders. Journal of Learning Disabilities 40(2):111-120.

Wineburg, S. 2001. Historical thinking and other unnatural acts. Philadelphia: Temple University Press.

Zimmerman, J. 2002. Whose America? Culture wars in the public schools. Cambridge: Harvard University Press.

doi:10.1186/2196-419X-1-5

Cite this article as: Fitzgerald: An analysis of causal asyndetic constructions in United States history textbooks.

Functional Linguistics 2014 1:5.

\section{Submit your manuscript to a SpringerOpen ${ }^{\circ}$} journal and benefit from:

- Convenient online submission

- Rigorous peer review

- Immediate publication on acceptance

- Open access: articles freely available online

- High visibility within the field

- Retaining the copyright to your article

Submit your next manuscript at $\boldsymbol{\sim}$ springeropen.com 